\title{
In Turkish: Sentence Structure and Possible Sentences According to the Sequence of Elements
}

\author{
Filiz Mete \\ Correspondence: Filiz Mete, Assist. Prof. Dr., Bülent Ecevit University Ereğli Education Faculty Ereğli, Zonguldak \\ Turkey.
}

Received: August 17, 2016

doi:10.11114/jets.v4i10.1880
Accepted: August 30, $2016 \quad$ Online Published: September 14, 2016

URL: http://dx.doi.org/10.11114/jets.v4i10.1880

\begin{abstract}
This study aims to investigate the structure according to the order of the elements in the Turkish sentence and to determine the possible sentences that are produced according to this structure. In order to examine the possible sentences, the question raised is: "How many possible canonical clauses (regular), inverted sentences (irregular) and elliptical (incomplete) sentences in Turkish can be created?" There are 24 possible sentences in canonical structure in which the position of the verb is fixed and other elements change positions. Inverted sentences are grouped under four groups: hence, there are 96 sentences. Elliptical sentence is formed with the reduction of one or more elements from the sentence and there are 205 possible sentences in elliptical sentence structure. No structural changes or affixes occur in the words that form the sentence. The same words are used in the same structure. As a conclusion, it is found out that the total number of possible canonical and inverted sentences are $24+24+24+24+24=120$ and the number of elliptical sentences are $5+20+60+120=205$. This indicates that we can form $(24+96+205=325) 325$ possible sentences in Turkish.
\end{abstract}

Keywords: sentence structure, canonical clauses sentence, inverted sentence, elliptical sentence

\section{Introduction}

\subsection{The General Characteristics of Turkish}

The number of languages that have been spoken and used in the world up to the present day is 7000 according to the linguists (Cengiz, 2011). Each language has similarities and differences with its own unique system. However, Sir William Jones spotted the affinity among Indo-European languages for the first time in 1786 after examining the origins of languages (Arikoğlu, 2009) and by this way, it was realized that languages could be classified based on their origins. According to the studies conducted so far, languages are classified into language families as follows:

1. Afro-Asiatic Languages

2. Indo-European Languages

3. Sino-Tibetan Languages

4. Niger-Congo Languages

5. Ural-Altaic Languages

Turkish language belongs to Ural-Altaic language family's Altaic group (Sar1, 2011), which include languages where there is affinity among them in terms of their origins. German Schleicher (Onan, 2009) classified languages as radical languages, agglutinating languages and fusional or inflected languages. Accordingly, languages are classified as follows based on the similarities on their grammatical structures:

1. Radical World Languages (Formless, Isolating)

2. Fusional or Inflected Languages (Conjugated))

3. Agglutinating Languages (Linked, Coherent)

Turkish takes place in agglutinative language group where inflection is performed by adding suffixes to the root-words. Ercilasun (2013) states that world languages are classified into six groups according to the sequence of sentence elements. The word-order groups are as follows:

1. Subject Verb Object 


\section{Subject Object Verb}

3. Verb Subject Object

4. Verb Object Subject

5. Object Verb Subject

6. Object Subject Verb

Turkish falls into the second group "Subject- Object- Verb" according to the sequence of word order.

\subsection{Sentence Elements in Turkish Sentence Structure}

The verb and other components that accompany the verb in terms of function and meaning are the elements of a sentence. These elements could be just one word or groups of words (phrases). These components make it possible to form accurate and meaningful sentences. There are 5 elements that make a sentence:

- Verb

- Subject

- Object

- Indirect Object

- Adverbial Clause

Sentence is a group of words that are put together to express a complete thought, action, emotion and incident (event). It is necessary that at least a transitive verb (verbal sentences) or a noun with a complementary verb (noun clauses) must function as the verb to be able to form a sentence. For example, the word "Götürdüm." in Turkish is a sentence all alone. The other elements in the sentence complement the verb in terms of meaning and function. Verb and subject are the basic elements, the other are complementary elements of the sentence (Ergin, 2009).

There are three groups of complementary elements in Turkish sentence structure:

- Object

- Indirect Object

- Adverbial Clause

Turkish sentences can be put into three main groups according to the sequence of sentence elements: canonical clauses (regular sentences), inverted clauses (irregular sentences) and elliptical (incomplete) sentences. Language rules are derived from the structure of the language and its historical background and these rules are not unchangeable, strict, and certain vice versa flexible (Vural and Böler, 2012).

\subsection{Purpose of this Study}

The aim of this study is to investigate the structure according to the order of the elements in the Turkish sentence and to determine the possible sentences that are produced in accordance with this structure. In this context, the research problem of this research is: "What are the possible sentences, according to the order of the elements?".

In order to examine research question, these sub research questions are asked: In Turkish;

1. How many possible canonical clauses (regular) sentences can be created?

2. How many possible inverted sentence (irregular) sentences can be created?

3. How many possible elliptical (incomplete) sentences can be created?

\section{Method}

A sample sentence is selected to study in Turkish that includes all the elements (main elements and auxiliary elements). "Ben kedimi bugün okula götürdüm. (I took my cat to school today.)" is the sample sentence. Words and tasks of the words in the sentence are given in the following table.

Table 1. Sentence elements and words used in the study

\begin{tabular}{lcccc}
\hline verb & subject & indirect object & adverbial clause & object \\
\hline götürdüm & ben & okula & bugün & kedimi \\
\hline
\end{tabular}

Possible sentences are created by using the same words as in the sample sentence. There are changes neither in the roots nor in the supplements of the words. 


\section{Results}

\subsection{Canonical Clauses}

According to canonical sentence structure, the verb must come at the end of the sentence

(1) The verb signals an action, occurrence or a state of being which expresses an activity and it is the finite component that completes a sentence. It is the main element of a sentence. The verb could be one word or a group of words. Other elements exist in the sentence to complete the meaning of the verb.

(2) The subject is the element that fulfills the action or occurrence signaled by the verb or it is the element, about which information is given by means of the verb, and it answers the questions "who" or "what", which are asked to the verb.

(3) Indirect object is the element that complements the meaning of the verb in terms of place, being present and movement. It usually takes -e, -de, and -den suffixes and answers the questions "where to, where from, who, what, why" that are asked to the verb.

(4) Adverbial clause expresses when, why, how, how much/many and in what way the action and occurrence signaled by the verb takes place. Prepositional clauses are also accepted as adverbial clauses.

(5) The object is the entity or concept, which is acted upon by the subject and affected by the action or occurrence signaled by the verb. The questions "who and what" are asked to the verb to find out direct object whereas the indirect object precedes the direct object and identified by asking questions "who or what receives the direct object".

The questions (who/what), which are mentioned in the explanations above, are used to determine the elements of a sentence. When we consider the sentence, "Ben bugün kedimi okula götürdüm.", if we address the elements of a sentence as: $1=$ the verb, $2=$ the subject, $3=$ indirect object, $4=$ adverbial clause, $5=$ the object, the sequence of sentence elements could be given as follows; 2 (ben) -4 (bugün) -5 (kedimi) -3 (okula) -1 (götürdüm)

In regular sentence structure, the verb must be placed at the end of sentence. As a mathematical term, "permutation" indicates the arrangement or the sequence of different elements in various forms. In this context, when a sentence is formed on condition that the verb is at the end position, the question of how many different forms could 4 out of 5 elements be arranged is answered by permutation. Hence, the number of regular sentences formed with 4 elements on condition that the verb is at the end, equals to the permutation of 4.

$$
4 !=4 \cdot 3 \cdot 2 \cdot 1=24 \text {. }
$$

In this way, based upon the given example, we will have 24 possible regular sentences in which there are 5 elements. While only one element (the verb) is fixed, other elements change their positions.

\section{Ben bugün kedimi okula götürdüm}

2. Ben bugün okula kedimi götürdüm

3. Ben okula kedimi bugün götürdüm

4. Ben okula bugün kedimi götürdüm

5. Ben kedimi okula bugün götürdüm

6. Ben kedimi bugün okula götürdüm

7.Okula ben bugün kedimi götürdüm

8. Okula ben kedimi bugün götürdüm

9. Okula kedimi bugün ben götürdüm

10. Okula kedimi ben bugün götürdüm

11. Okula bugün kedimi ben götürdüm

12. Okula bugün ben kedimi götürdüm

\section{Bugün kedimi ben okula götürdüm}

14. Bugün kedimi okula ben götürdüm

15. Bugün ben kedimi okula götürdüm

16. Bugün ben okula kedimi götürdüm

17. Bugün okula ben kedimi götürdüm

18. Bugün okula kedimi ben götürdüm

19. Kedimi bugün okula ben götürdüm

20. Kedimi bugün ben okula götürdüm

21. Kedimi ben okula bugün götürdüm

22. Kedimi ben bugün okula götürdüm

23. Kedimi okula ben bugün götürdüm

24. Kedimi okula bugün ben götürdüm

When we group the possible regular sentences according to elements positioned at the beginning of the sentence on condition that the verb is at the end of sentence, there will be 4 groups:

A. The sentences beginning with the subject and ending with the verb.

B. The sentences beginning with an indirect object and ending with the verb.

C. The sentences beginning with an adverbial clause and ending with the verb.

D. The sentences beginning with the object and ending with the verb. 
Table 2. Possible sentences in canonical clauses

\begin{tabular}{llll}
\hline A & B & C & D \\
\hline 1.Ben bugün kedimi okula & 1.Okula ben bugün kedimi & 1.Bugün kedimi ben okula & 1.Kedimi bugün okula ben \\
götürdüm. & götürdüm. & götürdüm. & götürdüm. \\
2.Ben bugün okula kedimi & 2.Okula ben kedimi bugün & 2.Bugün kedimi okula ben & 2. Kedimi bugün ben okula \\
götürdüm. & götürdüm. & götürdüm. & götürdüm. \\
3.Ben okula kedimi bugün & 3.Okula kedimi bugün ben & 3.Bugün ben kedimi okula & 3.Kedimi ben okulabugün \\
götürdüm. & götürdüm. & göttürdüm. & götürdüm. \\
4.Ben okula bugün kedimi & 4.Okula kedimi ben bugün & 4.Bugün ben okula kedimi & 4.Kedimi ben bugün okula \\
götürdüm. & götürdüm. & göttürdüm. & götürdüm. \\
5.Ben kedimi okula bugün & 5.Okula bugün kedimi ben & 5.Bugün okula ben kedimi & 5.Kedimi okula ben bugün \\
götürdüm. & götürdüm. & götürdüm. & götürdüm. \\
6.Ben kedimi bugün okula & 6.Okula bugün ben kedimi & 6.Bugün okula kedimi ben & 6.Kedimi okula bugün ben \\
götürdüm. & götürdüm & götürdüm & götürdüm. \\
\hline
\end{tabular}

It is seen that there could be 6 sentences with the subject at the beginning and the verb at the end; 6 sentences where indirect object at the beginning and the verb is at the end. 6 sentences with an adverbial clause at the beginning and the verb is at the end; and finally, 6 sentences with the object at the beginning and the verb is at the end of sentence.

Thus, there will be 6 sentences in each group in canonical sentence structure in which one element (the verb) is at the end and one element is fixed at the beginning of sentence.

On the other hand, on condition that the verb is at the end and one of 4 sentence elements is fixed at the beginning, the question of how many different positions can remaining three elements be arranged will be answered by permutation. This number will be equal to the permutation we get when we exclude the elements at the beginning and at the end of the sentence. 3 ! =3.2.1=6 as is seen, by arranging 3 different sentence elements in 6 different ways/forms, we can get 6 different sentence structures where one element is at the beginning and one element at the end.

The structure of the words in all sentences is the same. However, when the positions of the words are changed, the meaning of the sentence changes because the significance of the elements is determined according to their proximity to the verb. The importance is hinted with stress in spoken language (Demir, Y1lmaz, 2012). On condition that the verb is at the end, the most stressed element in possible sentences formed by changing the positions of elements is the element, which is the nearest to the verb. In this context, the message can vary because it is determined by the nearest element to the verb. The most stressed element in possible sentences is indicated by this sequence:

\section{$1 \rightarrow$ the verb, $2 \rightarrow$ the subject, $3 \rightarrow$ indirect object, $4 \rightarrow$ adverbial clause, $5 \rightarrow$ the object}

Table 3. Different meanings according to the place of the words

\begin{tabular}{|c|c|c|c|}
\hline $\begin{array}{l}\text { My cat is taken to the } \\
\text { school by me, not } \\
\text { someone else. }\end{array}$ & $\begin{array}{c}\text { I take my cat to the school, } \\
\text { not to other places. }\end{array}$ & $\begin{array}{l}\text { I take my cat today, not } \\
\text { other days. }\end{array}$ & $\begin{array}{c}\text { I take my cat, } \text { not other } \\
\text { things. }\end{array}$ \\
\hline $\begin{array}{l}\text { Okula kedimi bugün } 2 \\
\text { götürdüm }\end{array}$ & $\begin{array}{l}\text { Ben bugün kedimi } 3 \\
\text { götürdüm }\end{array}$ & $\begin{array}{l}\text { Ben okula kedimi } 4 \\
\text { götürdüm }\end{array}$ & $\begin{array}{l}\text { Ben bugün okula } 5 \\
\text { götürdüm }\end{array}$ \\
\hline $\begin{array}{l}\text { Okula bugün kedimi } 2 \\
\text { götürdüm }\end{array}$ & $\begin{array}{l}\text { Ben kedimi bugün } 3 \\
\text { götürdüm }\end{array}$ & $\begin{array}{l}\text { Ben kedimi okula } 4 \\
\text { götürdüm }\end{array}$ & $\begin{array}{l}\text { Ben okula bugün } 5 \\
\text { götürdüm }\end{array}$ \\
\hline $\begin{array}{l}\text { Bugün kedimi okula } 2 \\
\text { götürdüm }\end{array}$ & $\begin{array}{l}\text { Bugün kedimi ben } 3 \\
\text { götürdüm }\end{array}$ & $\begin{array}{l}\text { Okula ben kedimi } 4 \\
\text { götürdüm }\end{array}$ & $\begin{array}{l}\text { Okula ben bugün } 5 \\
\text { götürdüm }\end{array}$ \\
\hline $\begin{array}{l}\text { Bugün okula kedimi } 2 \\
\text { götürdüm }\end{array}$ & $\begin{array}{l}\text { Bugün ben kedimi } 3 \\
\text { götürdüm }\end{array}$ & $\begin{array}{l}\text { Okula kedimi ben } 4 \\
\text { götürdüm }\end{array}$ & $\begin{array}{l}\text { Okula bugün ben } 5 \\
\text { götürdüm }\end{array}$ \\
\hline $\begin{array}{l}\text { Kedimi bugün okula } 2 \\
\text { götürdüm }\end{array}$ & $\begin{array}{l}\text { Kedimi bugün ben } 3 \\
\text { götürdüm }\end{array}$ & $\begin{array}{l}\text { Kedimi ben okula } 4 \\
\text { götürdüm }\end{array}$ & $\begin{array}{l}\text { Bugün ben okula } 5 \\
\text { götürdüm }\end{array}$ \\
\hline $\begin{array}{l}\text { Kedimi okula bugün } 2 \\
\text { götürdüm }\end{array}$ & $\begin{array}{l}\text { Kedimi ben bugün } 3 \\
\text { götürdüm }\end{array}$ & $\begin{array}{l}\text { Kedimi okula ben } 4 \\
\text { götürdüm }\end{array}$ & $\begin{array}{l}\text { Bugün okula ben } 5 \\
\text { götürdüm }\end{array}$ \\
\hline
\end{tabular}

As is seen, on condition that the verb is at the end of sentence, 4 different elements are stressed and the message varies according to the element. In this context, it is possible to say that although the structure of the words does not change and on condition that the verb is at the end, there will be four messages because of changing positions of sentence elements. The power of expression and the richness of Turkish language can be seen in its structural features.

\subsection{Inverted Sentences}

According to the word sequence of Turkish language, the verb must be placed at the end of a canonical (regular) sentence. However, Turkish language has a rich and mathematical structure and other elements could be placed at the end of a sentence in inverted sentence structures. In this study, inverted sentences can be classified under four groups.

A: Sentences ending with the subject,

B: Sentences ending with the object, 
C: Sentences ending with the indirect object,

D: Inverted sentences ending with the adverbial clauses

Only one example sentence is used for each type of sentence. The sequence of sentence elements is given in the table below. Considering "Ben bugün kedimi okula götürdüm.", if the order is given as;

$1=$ the verb, $2=$ the subject, $3=$ the indirect object, $4=$ the adverbial clause, $5=$ the object, the sequence of the elements could be shown as $\mathbf{2}$ ben $\rightarrow \mathbf{4}$ bugün $\rightarrow \mathbf{5}$ kedimi $\rightarrow \mathbf{3 o k u l a} \rightarrow \mathbf{1}$ götürdüm.

Group A: Sentences ending with the subject

When sentences are formed based on inverted sentence structure on condition that the subject is at the end, we can answer the question of how many different forms are possible with 4 elements out of 5 by using permutation. As a mathematical term, "permutation" indicates the arrangement and the order of different elements in various forms.

Thus, the number of inverted sentences formed with 4 remaining elements out of 5 on condition that the subject is at the end equals to the permutation of $4.4 !=4 \cdot 3 \cdot 2 \cdot 1=24$

Six sentences in which the verb is at the beginning and the subject is at the end; six sentences starting with indirect object and ending with the subject; six sentences starting with adverbial clause and ending with the subject and finally six sentences starting with the object and ending with the subject are possible arrangements.

Hence, there will be six sentences in each group of inverted sentence structure where there are 5 elements and the subject (2) is at the end and one element is fixed at the beginning of the sentence.

On the other hand, we can answer the question of how many different variations can be used to arrange remaining 3 elements by permutation on condition that the subject is at the end and any of four elements is fixed at the beginning. This number will be equal to permutation of $3.3 !=3.2 .1=6$ that we can get when we exclude sentence elements at the beginning and at the end of a sentence. As it could be seen, three different sentence elements can be arranged in 6 different ways and 6 different sentence structures could be formed with one element at the beginning and one element at the end. In this way, the total number of sentences will be 24 . Based on the example sentence, there will be 24 possible sentences in an inverted sentence structure where there are 5 elements and the subject's position is fixed but the other elements change positions.
1. Götürdüm okula kedimi bugün ben
13. Bugün götürdüm kedimi okula ben
2. Götürdüm okula bugün kedimi ben
14. Bugün götürdüm okula kedimi ben
3. Götürdüm kedimi bugün okula ben
15. Bugün kedimi götürdüm okula ben
4. Götürdüm kedimi okula bugün ben
16. Bugün kedimi okula götürdüm ben
5. Götürdüm bugün kedimi okula ben
17. Bugün okula kedimi götürdüm ben
6. Götürdüm bugün okula kedimi ben
18. Bugün okula götürdüm kedimi ben
7.Okula götürdüm kedimi bugün ben
19. Kedimi götürdüm bugün okula ben
8. Okula götürdüm bugün kedimi ben
20. Kedimi götürdüm okula bugün ben
9. Okula kedimi götürdüm bugün ben
21. Kedimi bugün götürdüm okula ben
10. Okula kedimi bugün götürdüm ben
22. Kedimi bugün okula götürdüm ben
11. Okula bugün kedimi götürdüm ben
23. Kedimi okula götürdüm bugün ben
12. Okula bugün götürdüm kedimi ben
24. Kedimi okula bugün götürdüm ben

We will have 4 groups when we classify possible inverted sentences on condition that the subject is at the end according to elements at the beginning position

A .Sentences starting with the verb and ending with the subject

B. Sentences starting with the indirect object and ending with the subject

C. Sentences starting with the adverbial clause and ending with the subject

D. Sentences starting with the object and ending with the subject 
Table 4. Possible sentences in inverted sentence

\begin{tabular}{llll}
\hline A & B & C & \multicolumn{1}{c}{ D } \\
\hline 1.Götürdüm okula kedimi & 1.Okula götürdüm kedimi & 1.Bugün götürdüm kedimi & 1.Kedimi götürdüm bugün \\
bugün ben & bugün ben & okula ben & okula ben \\
2.Götürdüm okula bugün & 2.Okula götürdüm & 2.Bugün götürdüm & 2.Kedimi götürdüm \\
kedimi ben & bugün kedimi ben & okula kedimi ben & okula bugün ben \\
3.Götürdüm kedimi & 3.Okula kedimi götürdüm & 3.Bugün kedimi götürdüm & 3.Kedimi bugün götürdüm \\
bugün okula ben & bugün ben & okula ben & okula ben \\
4.Götürdüm kedimi okula & 4.Okula kedimi & 4.Bugün kedimi & 4.Kedimi bugün \\
bugün ben & bugün götürdüm ben & okula götürdüm ben & okula götürdüm ben \\
5.Götürdüm bugün & 5.Okula bugün & 5.Bugün okula & 5.Kedimi okula \\
kedimi okula ben & kedimi götürdüm ben & kedimi götürdüm ben & götürdüm bugün ben \\
6.Götürdüm bugün okula & 6.Okula bugün & 6.Bugün okula & 6.Kedimi okula \\
kedimi ben & götürdüm kedimi ben & götürdüm kedimi ben & bugün götürdüm ben \\
\hline
\end{tabular}
Group B: Sentences ending with the indirect object

The number of inverted sentences formed with remaining 4 elements out of 5 on condition that indirect object is at the end will be equal to the permutation of $4.4 !=4.3 .2 .1=24$

We can form six sentences with the verb at the beginning position and the indirect object at the end, six sentences with the object at the beginning position and the indirect object at the end, six sentences with the adverbial clause at the beginning position and the indirect object at the end, and six sentences with the object at the beginning position and the adverbial clause at the end. Hence, there will be six inverted sentences in each group with the indirect object at the end position and one element is fixed at the beginning position.

On the other hand, the questions of how many different ways could the remaining 3 elements be arranged could be answered by permutation on condition that indirect object is at the end and any of the remaining 4 elements is fixed at the beginning. This number will be equal to permutation of $3.3 !=3.2 .1=6$ that we get when we exclude elements at the beginning and at the end. As it is seen, 3 different elements could be arranged in 6 different ways and 6 different sentence structures could be formed where one element is at the beginning and indirect object is at the end. The total number of sentences will be 24 .

Based on the example sentence, there will be 24 sentences in inverted sentence structure in which there are 5 elements and indirect object's (3) position is fixed and other elements can change positions.

\begin{tabular}{|c|c|}
\hline 1. Götürdüm ben kedimi bugün okula & 13. Bugün götürdüm ben kedimi okula \\
\hline 2. Götürdüm ben bugün kedimi okula & 14. Bugün götürdüm kedimi ben okula \\
\hline 3. Götürdüm bugün ben kedimi okula & 15. Bugün kedimi götürdüm ben okula \\
\hline 4. Götürdüm bugün kedimi ben okula & 16. Bugün kedimi ben götürdüm okula \\
\hline 5. Götürdüm kedimi ben bugün okula & 17. Bugün ben götürdüm kedimi okula \\
\hline 6. Götürdüm kedimi bugün ben okula & 18. Bugün ben kedimi götürdüm okula \\
\hline 7. Ben götürdüm kedimi bugün okula & 19. Kedimi götürdüm ben bugün okula \\
\hline 8. Ben götürdüm bugün kedimi okula & 20. Kedimi götürdüm bugün ben okula \\
\hline 9. Ben kedimi götürdüm bugün okula & 21. Kedimi ben götürdüm bugün okula \\
\hline 10. Ben kedimi bugün götürdüm okula & 22. Kedimi ben bugün götürdüm okula \\
\hline 11. Ben bugün götürdüm kedimi okula & 23. Kedimi bugün götürdüm ben okula \\
\hline 12. Ben bugün kedimi götürdüm okula & 24. Kedimi bugün ben götürdüm okula \\
\hline
\end{tabular}

Table 5. Possible sentences in inverted sentence

\begin{tabular}{llll}
\hline A & B & C & D \\
\hline 1. Götürdüm ben & 1. Ben götürdüm & 1. Bugün götürdüm & 1. Kedimi götürdüm \\
kedimi bugün okula & kedimi bugün okula & ben kedimi okula & ben bugün okula \\
2. Götürdüm ben & 2. Ben götürdüm & 2. Bugün götürdüm kedimi & 2. Kedimi götürdüm \\
bugün kedimi okula & bugün kedimi okula & ben okula & bugün ben okula \\
3. Götürdüm bugün & 3. Ben kedimi & 3. Bugün kedimi götürdüm & 3. Kedimi ben \\
ben kedimi okula & götürdüm bugün okula & ben okula & götürdüm bugün okula \\
4. Götürdüm bugün & 4. Ben kedimi & 4. Bugün kedimi & 4. Kedimi ben \\
kedimi ben okula & bugün götürdüm okula & ben götürdüm okula & bugün götürdüm okula \\
5. Götürdüm kedimi & 5. Ben bugün & 5. Bugün ben & 5. Kedimi bugün \\
ben bugün okula & götürdüm kedimi okula & götürdüm kedimi okula & götürdüm ben okula \\
6. Götürdüm kedimi & 6. Ben bugün & 6. Bugün ben & 6. Kedimi bugün \\
bugün ben okula & kedimi götürdüm okula & kedimi götürdüm okula & ben götürdüm okula \\
\hline
\end{tabular}

Group C: Sentences ending with the adverbial clause

Consequently, the number of inverted sentences formed with the remaining four elements on condition that adverbial clause is at the end will be equal to the permutation of $4.4 !=4.3 .2 .1=24$ 
It is noticed that we can form six sentences with the verb at the beginning and adverbial clause at the end and six sentences with indirect object at the beginning and adverbial clause at the end. In addition, six sentences with the subject at the beginning and adverbial clause at the end and six sentences with the object at the beginning and adverbial clause at the end are possible.

Hence, there will be 6 sentences in each group in inverted sentence structure where adverbial clause (4) is at the end and one element is fixed at the beginning.

On the other hand, on condition that adverbial clause is at the end and any of the four elements is fixed at the beginning, the question of how many different ways could the remaining three elements be arranged is answered by permutation. This number will be equal to permutation of $3.3 !=3.2 .1=6$ that we could get when we exclude elements at the beginning and at the end. As such, three different sentence elements are arranged in six different ways and 6 different sentence structures in which one element is at the beginning and adverbial clause is at the end could be formed. In this way, the number of sentences will be 24 .

Based on the example sentence, we will form 24 possible sentences in inverted structure where the position of adverbial clause is fixed and other 4 elements change positions.
1. Götürdüm ben kedimi okula bugün
13. Okula götürdüm ben kedimi bugün
2. Götürdüm ben okula kedimi bugün
14. Okula götürdüm kedimi ben bugün
3. Götürdüm okula ben kedimi bugün
15. Okula ben götürdüm kedimi bugün
4. Götürdüm okula kedimi ben bugün
16. Okula ben kedimi götürdüm bugün
5. Götürdüm kedimi ben okula bugün
17. Okula kedimi götürdüm ben bugün
6. Götürdüm kedimi okula ben bugün
18. Okula kedimi ben götürdüm bugün
7. Ben götürdüm kedimi okula bugün
19. Kedimi götürdüm ben okula bugün
8 . Ben götürdüm okula kedimi bugün
20. Kedimi götürdüm okula ben bugün
9. Ben kedimi götürdüm okula bugün
21. Kedimi ben götürdüm okula bugün
10. Ben kedimi okula götürdüm bugün
22. Kedimi ben okula götürdüm bugün
11. Ben okula götürdüm kedimi bugün
23. Kedimi okula götürdüm ben bugün
12. Ben okula kedimi götürdüm bugün
24. Kedimi okula ben götürdüm bugün

Table 6. Possible sentences in inverted sentence

\begin{tabular}{llll}
\hline A & B & C & D \\
\hline 1. Götürdüm ben & 1. Ben götürdüm & 1. Okula götürdüm & 1. Kedimi götürdüm \\
kedimi okula bugün & kedimi okula bugün & ben kedimi bugün & ben okula bugün \\
2. Götürdüm ben & 2. Ben götürdüm & 2. Okula götürdüm & 2. Kedimi götürdüm \\
okula kedimi bugün & okula kedimi bugün & kedimi ben bugün & okula ben bugün \\
3. Götürdüm okula & 3. Ben kedimi & 3. Okula ben & 3. Kedimi ben \\
ben kedimi bugün & götürdüm okula bugün & götürdüm kedimi bugün & götürdüm okula bugün \\
4. Götürdüm okula & 4. Ben kedimi & 4. Okula ben & 4. Kedimi ben \\
kedimi ben bugün & okula götürdüm bugün & kedimi götürdüm bugün & okula götürdüm bugün \\
5. Götürdüm kedimi & 5. Ben okula & 5. Okula kedimi & 5. Kedimi okula \\
ben okula bugün & götürdüm kedimi bugün & götürdüm ben bugün & götürdüm ben bugün \\
6. Götürdüm kedimi & 6. Ben okula & 6. Okula kedimi & 6. Kedimi okula \\
okula ben bugün & kedimi götürdüm bugün & ben götürdüm bugün & ben götürdüm bugün \\
\hline
\end{tabular}

Group D: Sentences ending with the object

Thereby, the number of inverted sentences formed with remaining 4 elements out of 5 on condition that the object is at the end will be equal to the permutation of four. $4.4 !=4 \cdot 3 \cdot 2 \cdot 1=24$

We can say that six sentences with the verb at the beginning and the object at the end; six sentences with indirect object at the beginning and the object at the end could be formed. We could form other six sentences with adverbial clause at the beginning, the object at the end and finally six sentences with the subject at the beginning, and the object at the end. 
Hence, there will be 6 sentences in each group in inverted structure where the object is at the end and one element is fixed at the beginning.

On the other hand, the question of how many ways can remaining 3 elements be arranged on condition that the object is at the end and any of remaining 4 elements is fixed at the beginning could be answered by permutation. This number will be equal to the permutation $3 \cdot 3 !=3 \cdot 2 \cdot 1=6$ that we get when we exclude the elements at the beginning and at the end of sentence. As is seen, 3 difference sentence elements could be arranged in 6 different ways and we form 6 different sentence structures in which the object is at the end and one of the elements is at the beginning. In this way, we can get 24 different sentences.

Based on the example sentence, there will be 24 possible inverted sentences where the position of the object (5) is fixed and other elements change positions.

\begin{tabular}{ll}
\hline 1. Götürdüm ben okula bugün kedimi & 13. Okula götürdüm ben bugün kedimi \\
2. Götürdüm ben bugün okula kedimi & 14. Okula götürdüm bugün ben kedimi \\
3. Götürdüm okula ben bugün kedimi & 15. Okula ben götürdüm bugün kedimi \\
4. Götürdüm okula bugün ben kedimi & 16. Okula ben bugün götürdüm kedimi \\
5. Götürdüm bugün ben okula kedimi & 17. Okula bugün götürdüm ben kedimi \\
6. Götürdüm bugün okula ben kedimi & 18. Okula bugün ben götürdüm kedimi \\
7. Ben götürdüm okula bugün kedimi & 19. Bugün götürdüm ben okula kedimi \\
8. Ben götürdüm bugün okula kedimi & 20. Bugün götürdüm okula ben kedimi \\
9. Ben okula götürdüm bugün kedimi & 21. Bugün ben okula götürdüm kedimi \\
10. Ben okula bugün götürdüm kedimi & 22. Bugün ben götürdüm okula kedimi \\
11. Ben bugün götürdüm okula kedimi & 23. Bugün okula ben götürdüm kedimi \\
12. Ben bugün okula götürdüm kedimi & 24. Bugün okula götürdüm ben kedimi \\
\hline
\end{tabular}

Table 7. Possible sentences in inverted sentence

\begin{tabular}{llll}
\hline A & B & C & D \\
\hline 1. Götürdüm ben & 1. Ben götürdüm & 1. Okula götürdüm & 1. Bugün götürdüm \\
okula bugün kedimi & okula bugün kedimi & ben bugün kedimi & ben okula kedimi \\
2. Götürdüm ben & 2. Ben götürdüm & 2. Okula götürdüm & 2. Bugün götürdüm \\
bugün okula kedimi & bugün okula kedimi & bugün ben kedimi & okula ben kedimi \\
3. Götürdüm okula & 3. Ben okula & 3. Okula ben & 3. Bugün ben \\
ben bugün kedimi & götürdüm bugün kedimi & götürdüm bugün kedimi & okula götürdüm kedimi \\
4. Götürdüm okula bugün & 4. Ben okula & 4. Okula ben & 4. Bugün ben \\
ben kedimi & bugün götürdüm kedimi & bugün götürdüm kedimi & götürdüm okula kedimi \\
5. Götürdüm bugün & 5. Ben bugün & 5. Okula bugün & 5. Bugün okula \\
ben okula kedimi & götürdüm okula kedimi & götürdüm ben kedimi & ben götürdüm kedimi \\
6. Götürdüm bugün okula & 6. Ben bugün & 6. Okula bugün & 6. Bugün okula \\
ben kedimi & okula götürdüm kedimi & ben götürdüm kedimi & götürdüm ben kedimi \\
\hline
\end{tabular}

\subsection{Elliptical Sentences}

A sentence without a verb is called elliptical (incomplete) sentence (Yelten, 2010:304). Actually an elliptical sentence is a shorter form of sentence in which one or more elements are removed or left out in a way that does not cause ambiguity or confusion. Especially, one-word sentences are often used in order not to repeat the question or sentence or give a chance to comment in spoken language. In this study, the language is not to divide in spoken and written language. But to use only the sample sentence is important.

It was determined possible elliptical sentences by using the sample sentence: "Ben kedimi bugün okula götürdüm". 
Table 8. Possible sentences in elliptical sentences that have four words

\begin{tabular}{|c|c|c|c|c|}
\hline $\begin{array}{l}\text { subject at the end of } \\
\text { sentences }\end{array}$ & $\begin{array}{l}\text { adverbial clause at the end } \\
\text { of sentences }\end{array}$ & $\begin{array}{l}\text { the object at the end } \\
\text { of sentences }\end{array}$ & $\begin{array}{l}\text { indirect object at the end of } \\
\text { sentences }\end{array}$ & $\begin{array}{l}\text { verb at the end of } \\
\text { sentences }\end{array}$ \\
\hline 1.Götürdüm okula & 1.Götürdüm ben & 1.Götürdüm ben & 1.Götürdüm ben & 1.Ben okula \\
\hline kedimi ben & okula bugün & okula kedimi & kedimi okula & kedimi götürdüm \\
\hline 2.Götürdüm okula & 2.Götürdüm ben & 2.Götürdüm ben & 2.Götürdüm ben & 2.Ben okula \\
\hline bugün ben & kedimi bugün & bugün kedimi & bugün okula & bugün götürdüm \\
\hline 3.Götürdüm kedimi & 3.Götürdüm okula & 3.Götürdüm okula & 3.Götürdüm bugün & 3.Ben bugün \\
\hline bugün ben & ben bugün & ben kedimi & ben okula & kedimi götürdüm \\
\hline 4.Götürdüm kedimi & 4.Götürdüm okula & 4.Götürdüm okula & 4.Götürdüm bugün & 4.Ben bugün \\
\hline okula ben & kedimi bugün & bugün kedimi & kedimi okula & okula götürdüm \\
\hline 5.Götürdüm bugün & 5.Götürdüm kedimi & 5.Götürdüm bugün & 5.Götürdüm kedimi & 5.Ben kedimi \\
\hline kedimi ben & ben bugün & ben kedimi & bugün okula & bugün götürdüm \\
\hline 6.Götürdüm bugün & 6.Götürdüm kedimi & 6.Götürdüm bugün & 6.Götürdüm kedimi & 6.Ben kedimi \\
\hline okula ben & okula bugün & okula kedimi & ben okula & okula götürdüm \\
\hline 7.Okula götürdüm & 7. Ben götürdüm & 7.Ben götürdüm & 7.Ben kedimi & 7.Bugün ben \\
\hline kedimi ben & okula bugün & okula kedimi & götürdüm okula & kedimi götürdüm \\
\hline 8.Okula götürdüm & 8. Ben götürdüm & 8.Ben götürdüm & 8.Ben kedimi & 8.Bugün ben \\
\hline bugün ben & kedimi bugün & bugün kedimi & bugün okula & okula götürdüm \\
\hline 9.Okula kedimi & 9. Ben kedimi & 9.Ben bugün & 9.Ben götürdüm & 9.Bugün kedimi \\
\hline götürdüm ben & götürdüm bugün & okula kedimi & kedimi okula & okula götürdüm \\
\hline 10.Okula kedimi & 10.Ben kedimi & 10.Ben bugün & 10.Ben götürdüm & 10.Bugün kedimi \\
\hline bugün ben & okula bugün & götürdüm kedimi & bugün okula & ben götürdüm \\
\hline 11.Okula bugün & 11.Ben okula & 11.Ben okula & 11.Ben bugün & 11.Bugün okula \\
\hline götürdüm ben & götürdüm bugün & götürdüm kedimi & kedimi okula & ben götürdüm 12.Bugün \\
\hline 12.Okula bugün & 12.Ben okula & 12.Ben okula & 12.Ben bugün & okula \\
\hline kedimi ben & kedimi bugün & bugün kedimi & götürdüm okula & kedimi götürdüm \\
\hline 13.Kedimi götürdüm & 13.Okula ben & 13.Okula götürdüm & 13.Kedimi ben & 13.Okula ben \\
\hline bugün ben & götürdüm bugün & ben kedimi & götürdüm okula & kedimi götürdüm \\
\hline 14.Kedimi götürdüm & 14.Okula ben & 14.Okula götürdüm & 14.Kedimi ben & 14.Okula ben \\
\hline okula ben & kedimi bugün & bugün kedimi & bugün okula & bugün götürdüm \\
\hline 15.Kedimi bugün & 15.Okula kedimi götürdüm & 15.Okula ben & 15.Kedimi götürdüm & 15.Okula kedimi \\
\hline götürdüm ben & bugün & götürdüm kedimi & ben okula & ben götürdüm \\
\hline 16.Kedimi bugün & 16.Okula kedimi & 16.Okula ben & 16.Kedimi götürdüm & 16.Okula kedimi \\
\hline okula ben & ben bugün & bugün kedimi & bugün okula & bugün götürdüm \\
\hline 17.Kedimi okula & 17.Okula götürdüm & 17.Okula bugün & 17.Kedimi bugün & 17.Okula bugün \\
\hline götürdüm ben & ben bugün & götürdüm kedimi & götürdüm okula & ben götürdüm \\
\hline 18.Kedimi okula & 18.Okula götürdüm kedimi & 18.Okula bugün & 18.Kedimi bugün & 18.Okula bugün \\
\hline bugün ben & bugün & ben kedimi & ben okula & kedimi götürdüm \\
\hline 19.Bugün götürdüm & 19.Kedimi götürdüm & 19.Bugün götürdüm & 19.Bugün götürdüm & 19.Kedimi ben \\
\hline okula ben & ben bugün & ben kedimi & ben okula & okula götürdüm \\
\hline 20.Bugün götürdüm & 20.Kedimi götürdüm okula & 20.Bugün götürdüm & 20.Bugün götürdüm & 20.Kedimi ben \\
\hline kedimi ben & bugün & okula kedimi & kedimi okula & bugün götürdüm \\
\hline 21.Bugün kedimi & 21.Kedimi ben & 21.Bugün ben & 21.Bugün ben & 21.Kedimi bugün \\
\hline götürdüm ben & götürdüm bugün 22. Kedimi & götürdüm kedimi & götürdüm okula & ben götürdüm \\
\hline 22.Bugün kedimi & ben & 22.Bugün ben & 22.Bugün ben & 22. Kedimi bugün \\
\hline okula ben & okula bugün & okula kedimi & kedimi okula & okula götürdüm \\
\hline 23.Bugün okula & 23.Kedimi okula götürdüm & 23.Bugün okula & 23.Bugün kedimi & 23.Kedimi okula \\
\hline götürdüm ben & bugün 24.Kedimi okula & götürdüm kedimi & götürdüm okula & ben götürdüm \\
\hline 24.Bugün okula & ben bugün & 24.Bugün okula & 24.Bugün kedimi & 24.Kedimi okula \\
\hline kedimi ben & & ben kedimi & ben okula & bugün götürdüm \\
\hline
\end{tabular}

There will be 24 sentences in which one out of five elements is missing and on condition that the verb is at the end, 24 sentences with the indirect object at the end, 24 sentences with adverbial clause at the end, 24 sentences with the object at the end and finally 24 sentences with the verb at the end. As a result, on condition that one element out of 5 is at the end, the number of elliptical sentences formed with remaining 4 words will be equal to the permutation of 4.4 ! $=4.3 .2 .1=24$ Hence, there will be total $120(24 \times 4)$ elliptical sentences because we will get four groups on condition that one element is missing and one element is at the end position. 
Table 9. Possible sentences in elliptical sentences that have three words

\begin{tabular}{|c|c|c|c|c|}
\hline $\begin{array}{l}\text { 1.Bugün kedimi } \\
\text { ben }\end{array}$ & $\begin{array}{l}\text { 1.Ben kedimi } \\
\text { bugün }\end{array}$ & $\begin{array}{l}\text { 1.Ben bugün } \\
\text { kedimi }\end{array}$ & $\begin{array}{l}\text { 1.Ben kedimi } \\
\text { okula }\end{array}$ & $\begin{array}{l}\text { 1.Ben bugün } \\
\text { götürdüm }\end{array}$ \\
\hline 2.Bugün okula & 2.Ben okula & 2.Ben okula & 2.Ben götürdüm & 2.Ben kedimi \\
\hline ben & bugün & kedimi & okula & götürdüm \\
\hline 3.Bugün götürdüm & 3.Ben götürdüm & 3.Ben götürdüm & 3.Ben bugün & 3.Ben okula \\
\hline ben & bugün & kedimi & okula & götürdüm \\
\hline 4.Kedimi okula & 4.Kedimi ben & 4.Bugün ben & 4.Bugün kedimi & 4.Bugün ben \\
\hline ben & bugün & kedimi & okula & götürdüm \\
\hline $\begin{array}{l}\text { 5.Kedimi bugün } \\
\text { ben }\end{array}$ & $\begin{array}{l}\text { 5.Kedimi okula } \\
\text { bugün }\end{array}$ & $\begin{array}{l}\text { 5.Bugün okula } \\
\text { kedimi }\end{array}$ & $\begin{array}{l}\text { 5.Bugün ben } \\
\text { okula }\end{array}$ & $\begin{array}{l}\text { 5.Bugün okula } \\
\text { götürdüm }\end{array}$ \\
\hline $\begin{array}{l}\text { 6.Kedimi götürdüm } \\
\text { ben }\end{array}$ & $\begin{array}{l}\text { 6.Kedimi götürdüm } \\
\text { bugün }\end{array}$ & $\begin{array}{l}\text { 6.Bugün götürdüm } \\
\text { kedimi }\end{array}$ & $\begin{array}{l}\text { 6.Bugün götürdüm } \\
\text { okula }\end{array}$ & $\begin{array}{l}\text { 6.Bugün kedimi } \\
\text { götürdüm }\end{array}$ \\
\hline 7.Okula kedimi & 7.Okula götürdüm & 7.Okula ben & 7.Kedimi ben & 7.Okula ben \\
\hline ben & bugün & kedimi & okula & götürdüm \\
\hline $\begin{array}{l}\text { 8.Okula bugün } \\
\text { ben }\end{array}$ & $\begin{array}{l}8 . \text { Okula ben } \\
\text { bugün }\end{array}$ & $\begin{array}{l}\text { 8. Okula bugün } \\
\text { kedimi }\end{array}$ & $\begin{array}{l}\text { 8.Kedimi bugün } \\
\text { okula }\end{array}$ & $\begin{array}{l}\text { 8.Okula kedimi } \\
\text { götürdüm }\end{array}$ \\
\hline $\begin{array}{l}\text { 9.Okula götürdüm } \\
\text { ben }\end{array}$ & $\begin{array}{l}\text { 9. Okula kedimi } \\
\text { bugün }\end{array}$ & $\begin{array}{l}\text { 9.Okula götürdüm } \\
\text { kedimi }\end{array}$ & $\begin{array}{l}\text { 9.Kedimi götürdüm } \\
\text { okula }\end{array}$ & $\begin{array}{l}\text { 9.Okula bugün } \\
\text { götürdüm }\end{array}$ \\
\hline $\begin{array}{l}\text { 10.Götürdüm kedimi } \\
\text { ben }\end{array}$ & $\begin{array}{l}\text { 10.Götürdüm ben } \\
\text { bugün }\end{array}$ & $\begin{array}{l}\text { 10.Götürdüm ben } \\
\text { kedimi }\end{array}$ & $\begin{array}{l}\text { 10.Götürdüm ben } \\
\text { okula }\end{array}$ & $\begin{array}{l}\text { 10.Kedimi ben } \\
\text { götürdüm }\end{array}$ \\
\hline $\begin{array}{l}\text { 11.Götürdüm okula } \\
\text { ben }\end{array}$ & $\begin{array}{l}\text { 11.Götürdüm kedimi } \\
\text { bugün }\end{array}$ & $\begin{array}{l}\text { 11.Götürdüm bugün } \\
\text { kedimi }\end{array}$ & $\begin{array}{l}\text { 11.Götürdüm bugün } \\
\text { okula }\end{array}$ & $\begin{array}{l}\text { 11.Kedimi bugün } \\
\text { götürdüm }\end{array}$ \\
\hline $\begin{array}{l}\text { 12.Götürdüm bugün } \\
\text { ben }\end{array}$ & $\begin{array}{l}\text { 12.Götürdüm okula } \\
\text { bugün }\end{array}$ & $\begin{array}{l}\text { 12.Götürdüm okula } \\
\text { kedimi }\end{array}$ & $\begin{array}{l}\text { 12.Götürdüm kedimi } \\
\text { okula }\end{array}$ & $\begin{array}{l}\text { 12.Kedimi okula } \\
\text { götürdüm }\end{array}$ \\
\hline
\end{tabular}

There will be 12 sentences formed with three words on condition that the subject is at the end and two of the words out of 5 words that form the sentence are missing. So are, 12 sentences with indirect object at the end; 12 sentences with adverbial clause at the end; 12 sentences with the object at the end; 12 sentences with the verb at the end. Thus, there will be five groups on condition that one element is missing and one element is at the end; consequently, there will be total 60 (12x5) elliptical sentences with three words.

Table 10. Possible sentences in elliptical sentences that have two words

\begin{tabular}{lllll}
\hline 1.Götürdüm ben & 1.Götürdüm bugün & 1.Götürdüm kedimi & 1.Götürdüm okula & 1.Ben götürdüm \\
2.Kedimi ben & 2.Kedimi bugün & 2.Okula kedimi & 2.Kedimi okula & 2.Kedimi götürdüm \\
3.Okula ben & 3.Okula bugün & 3.Ben kedimi & 3.Bugün okula & 3.Okula götürdüm \\
4.Bugün ben & 4.Ben bugün & 4.Bugün kedimi & 4.Ben okula & 4.Bugün götürdüm \\
\hline
\end{tabular}

There will be 4 sentences with two words on condition that the subject is at the end and three of 5 elements that form the sentence are missing. Also, there will be 4 sentences with two words on condition that indirect object is at the end; 4 sentences with the adverbial clause at the end; 4 sentences with the object at the end and finally 4 sentences with the verb at the end. Thus, as we have five groups on condition that one element is missing and one element is at the end, there will be total $20(5 \times 4)$ elliptical sentences with two words.

\subsection{Elliptical Sentences with One Word}

This type of sentence does not include basic elements necessary to form a full sentence. It is largely used with the purpose of not repeating the elements of question in the answer because of the "least effort" principle. When we consider the sentence, "Ben bugün kedimi okula götürdüm.", the answers of the questions below will be elliptical sentences with one word.

Kim bugün okula kedisini götürdü? (Who took the cat to school today?)

Ben.

Sen bugün neyi okula götürdün? (What did you take to school today?)

Kedimi.

Sen kedini ne zaman okula götürdün? (When did you take the cat to school?)

Bugün.

Sen bugün kedini nereye götürdün? (Where did you take the cat today?)

Okula.

Sen bugün kedini okula götürdün mü? (Did you take the cat to school today?)

Götürdüm. 
In this way, considering the example sentence, "Ben bugün kedimi okula götürdüm", there will be 5 elliptical sentences with one word on condition that 4 out of 5 elements are missing. In this context, elliptical sentences with one word are 1/5.

\section{Results}

The study conducted is based on the example sentence, "Ben kedimi bugün okula götürdüm." This sentence has 5 elements. Firstly, canonical sentence structure is examined and the number of canonical sentences formed with remaining four elements on condition that the verb is at the end is calculated by a mathematical term, permutation, which indicates various arrangements and the sequence of different elements in a sentence. In this case, the sentences formed based on the example sentence are equal to the permutation of $4(\mathbf{4} !=\mathbf{4 . 3 . 2 . 1}=\mathbf{2 4})$. Thus, there are 24 possible sentences in canonical structure in which the position of the verb is fixed and other elements change positions.

Inverted sentences are classified under four groups: (1) sentences ending with the subject, sentences ending with the object, sentences ending with the indirect object and sentences ending with the adverbial clause. Based on the example sentence, we have 24 possible sentences in inverted structure where the position of the subject is fixed (2) and other elements change positions. Based on the example sentence, we have 24 possible sentences in inverted structure where the position of indirect object is fixed (3) and other elements change positions. Based on the example sentence, we have 24 possible sentences in inverted structure where the position of adverbial clause (4) is fixed and other elements change positions. Based on the example sentence, we have 24 possible sentences in inverted structure where the position of the object is fixed and other elements change positions. Hence, there are 96 sentences.

Elliptical sentence is formed with the reduction of one or more elements from the sentence and there are 5 sentences with one word, 20 sentences with two words, 60 sentences with three words and 120 sentences with four words. We have total 205 possible sentences in elliptical sentence structure.

As a conclusion, it is found out that the total number of possible canonical and inverted sentences are $24+24+24+24+24=120$ and the number of elliptical sentences are $5+20+60+120=205$. No structural changes or affixes occur in the words that form the sentence. The same words are used in the same structure. This indicates that we can form $(24+96+205=325) 325$ possible sentences in Turkish based on a sentence with 5 words.

\section{References}

Arıkoğlu, E. (2009). Nostratik dil teorisi içerisinde Altay dilleri. Turkish Studies, 4(8), 177- 184.

Cengiz, M. (2011). Dillerin katli, Hacettepe Üniversitesi Türkiyat Araştırmaları Dergisi, Güz (15), 459-464.

Ercilasun, A. (2013). Türkçenin dünya dilleri arasındaki yeri. Dil Araştırmaları, 17-22.

Ergin, M. (2009). Üniversiteler için Türk dili. İstanbul: Bayrak Basım/Yayım/Tanıtım.

Onan, B. (2009). Eklemeli dil yapısının Türkçe öğretiminde oluşturduğu bilişsel (kognitif) zeminler. Mustafa Kemal Üniversitesi Sosyal Bilimler Enstitüsü Dergisi, 6(11), 237-264.

Sarı, M. (2011). Türk dili ders kitabı. Ankara: Okutman Yayıncılık.

Vural, H., \& Böler, T. (2012). Ses ve şekil bilgisi. İstanbul: Kesit Yayınları.

Yelten, M. (2010). Türk dili ve anlatım bilgileri. İstanbul: Doğu Kütüphanesi. 